\title{
Evaluation of Colored Sticky Traps for Monitoring and Managing the Jassid Population in Okra
}

\author{
Tufail Ahmed Wagan $^{1 *} \quad$ Mudaser Ali Jessar $^{1} \quad$ Nusrat Hussain Abbasi $^{1} \quad$ Shahnawaz Khuhro $^{2}$ \\ Mehran Ali Abro ${ }^{1} \quad$ Abdul Naeem Bughio ${ }^{1} \quad$ Abdul Samee Junejo $^{1}$ Ghulam Murtaza Pathan ${ }^{1}$ \\ 1.Department of Plant Protection, Sindh Agriculture University SZABAC Dokri \\ 2.Department of Entomology, Sindh Agriculture University SZABAC Dokri
}

\begin{abstract}
This field experiment was designed to observe jassid's (Amrasca devastans) attraction to sticky paper with four different colors (yellow, black, red, and green) positioned in okra crops. The colored sticky papers were placed on wooden sticks that were positioned randomly 5 meters apart between sheets and $30 \mathrm{~cm}$ above the plant. The results of this experiment showed that the green, followed by red, black, and yellow, sticky paper is the most effective, attractive, and convenient colored paper for controlling the jassid population in okra crops. The sticky colored cards are an alternative, effective, and exclusive tool for managing the jassid population in okra crops.
\end{abstract}

DOI: $10.7176 / \mathrm{JBAH} / 9-11-05$

Publication date:June $30^{\text {th }} 2019$

\section{Introduction}

Okra (Abelmoschus esculentus L. Moench), called "Bhindi" by the local population in IndoPak sub-continent, belongs to the Malvecea family and is one of the most important vegetables in the world, especially in the tropical and subtropical regions, where it is grown mainly for human consumption (Mangrio, 2004; Alegbejo et al., 2008). However, the vegetative parts of okra are often infested by a large number of sucking and chewing insect pests, which affects the expected yield during the harvest period. The most destructive insect pests include the following: the whitefly, Bemisia tabaci (Genn.), Thrips tabaci (Lind.), jassid, Amrasca devastans (Dist.), aphid, Aphis gossypii (Glover), American bollworm, Helicoverpa armigera (Hb.), spotted bollworm, and Earias spp. (Shabozoi et al., 2011; Aziz et al., 2011). Such pests are normally controlled using hazardous chemicals, which can have a negative impact on the environment. Therefore, safe, analogous controls are needed. Trapping is the most convenient and inexpensive tool for pest monitoring and management. Colored sticky-traps are simple, low-cost methods for identifying the relative abundance of insects and are used to monitor flying insect species in numerous crops (Lessio and Alma, 2004; Raja and Arivudainambi, 2004)

\section{Material and Methods}

Experiment

The field study was conducted at Shaheed Zulfiqar Ali Bhutto Agricultural College Dokri, which is at 27.3743 (N) north latitude, $68.0967^{\circ}$ (E) east longitude and has an altitude of 131 feet, during the kharif season (May to August). The purpose of the study was to evaluate the insect pests' attraction to different colors of sticky traps. Rama Krishna, a variety of okra, seeds were sown on both sides of well-prepared ridges. The rows were sown 40$45 \mathrm{~cm}$ apart and the plant-to-plant distance was $6-8 \mathrm{~cm}$. No pesticides were used for pest management throughout the research period. Irrigation and weeding were completed whenever they were needed.

Field studies

After 25 days of germination, four different colors (black, green, yellow, and red) of sticky papers $(25 \times 25 \mathrm{~cm})$ were placed randomly in the field using bamboo stakes. The cards were placed $5 \mathrm{~m}$ apart and $30 \mathrm{~cm}$ above the plants. The sticky cards were placed in the field in morning (from 8am to 9am) and replaced after 24 hours. Both the adult and nymph Jassids on each sticky card were counted and recorded. Then, 10 plants' height, leaves, squares, flowers, and fruits were recorded from each section (where each of the colors were positioned). The activity was repeated every week, and 12 collections of each color were tested. The obtained data was subjected to statistical analysis, and the figures were recorded using Microsoft Excel for Windows 2007.

\section{Results}

Green colored sticky cards

Based on total number of Jassid found on all the cards that were collected, the jassid population was the most attracted to the green sticky card. The Jassid population was recorded from the first week of the observations and had a mean of 14.92 jassids per card. Its population increased as the season progressed; the peak population was recorded during the $10^{\text {th }}$ week of observation and had a mean number of 58.27 jassids per card (Fig. 1). 


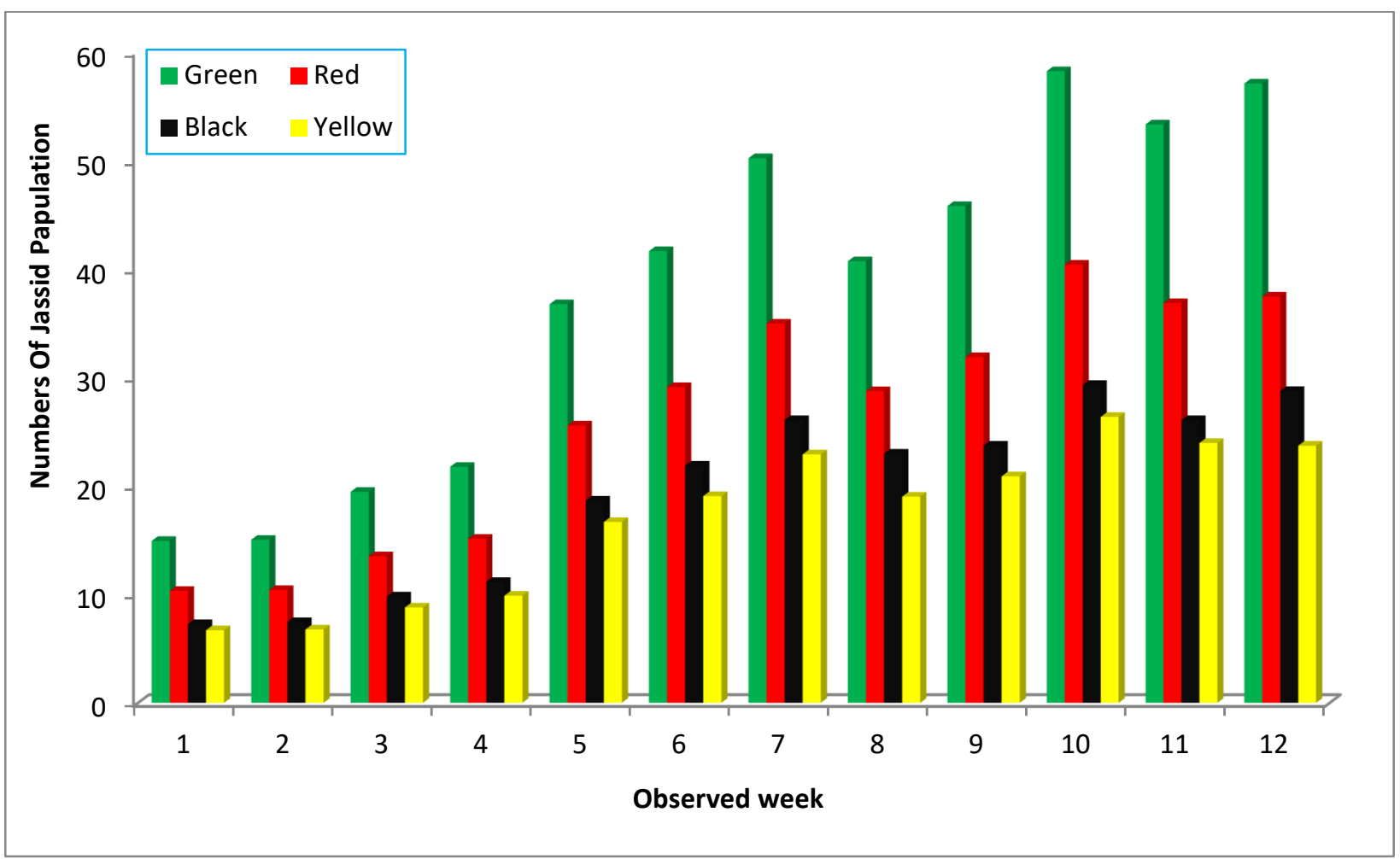

Figure 1. Population of Jassid on different colored sticky traps, values are mean of 10 replications.

Red colored sticky cards

The red colored card was the second-most attractive. The population was observed from the first week the jassid appeared on the sticky paper, but minimum data were recorded during the second week with mean number of 10.4 jassids per card. And the maximum jassid population was recorded during the $10^{\text {th }}$ week (mean 40.45 jassids per card) (Fig. 1).

Black colored sticky cards

The black colored card was the third-most attractive. The black colored card had a mean of 7.25 jassids per card during the first week, but the population increased with the passage of time. The highest jassid population was observed during the $10^{\text {th }}$ week (mean 29.29 jassids per card) (Fig. 1).

Yellow colored sticky cards

The yellow-colored card attracted the smallest population. The mean Jassid population recorded during the first week was 6.69 jassids per card, and the population increased with the passage of time. The $10^{\text {th }}$ week mean was 26.34 jassids per card. The yellow color is the least attractive among the colors tested (Fig. 1).

Plant vegetative growth

The plant height increased gradually as time progressed. During the first recording, the stem height was $15.35 \mathrm{~cm}$, and during the final recording it had grown to $70.69 \mathrm{~cm}$. The plant leaves also increased as the plant aged. During the first week, the plants had an average 6.21 leaves, and during the final recording, an average 24.93 leaves were recorded for each plant (Fig. 2). 


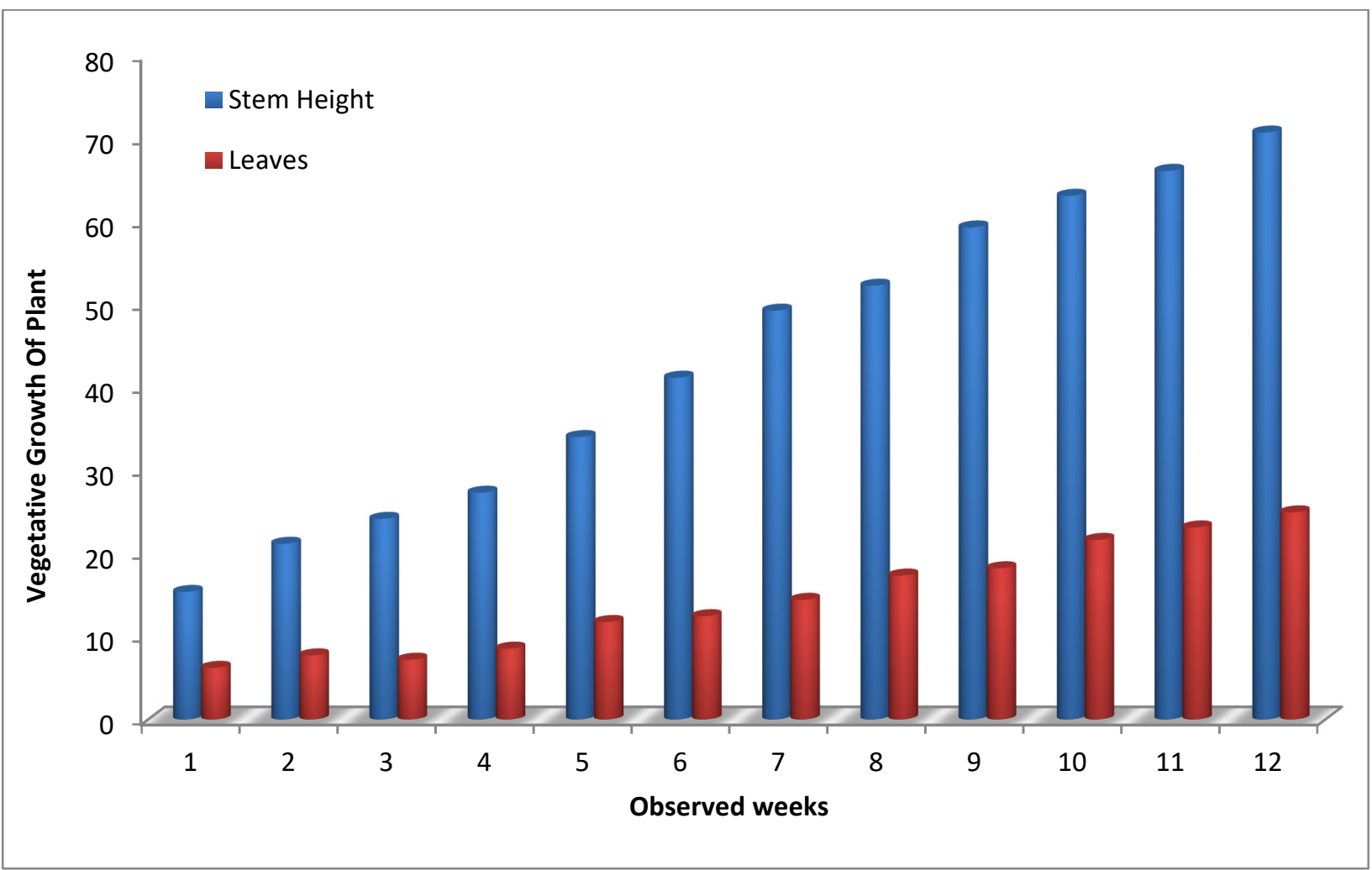

Figure 2. Vegetative growths of okra crop, values are the mean of 10 replications.

Plant reproductive growth

The square appeared on the plants during the third recording period with mean number of 2.30 squares per plant. The squares appeared continuously until the final observation (Fig. 3). The first flower was recorded during the fourth observation with a mean number of 1.3 flowers per plant, and flowering was continuously observed. Flowering increased as time progressed until the final recording (Fig. 3). The fruit also appeared during the fourth week of observation with a mean number of 1.40 fruit per plant, and the fruit appeared in increasing numbers until the final observation (Fig. 3).

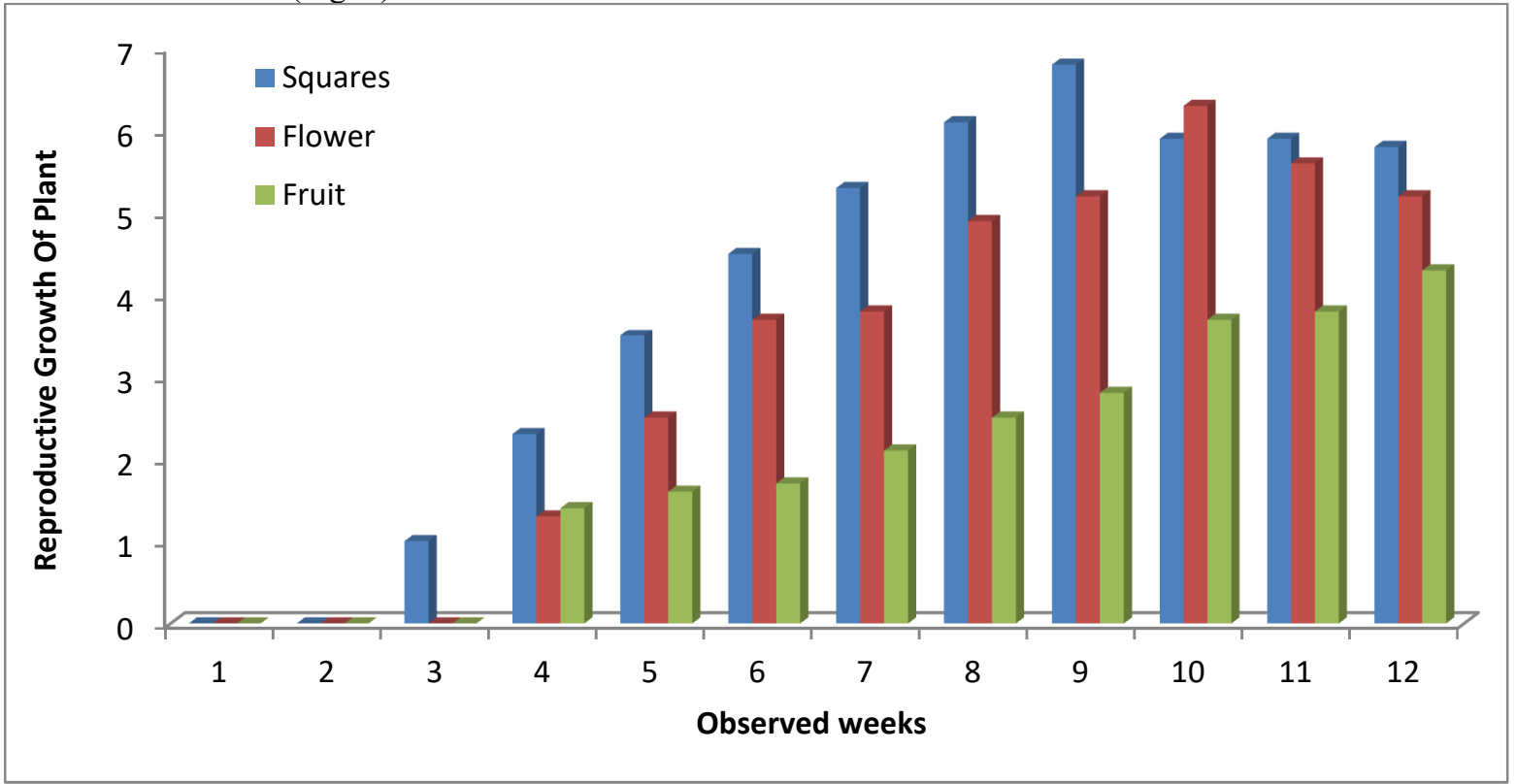

Figure 3. Reproductive growths of okra crop, values are the mean of 10 replications.

\section{Discussion}

The results showed that all the colored cards attracted the jassid population. Similar insect attraction results were 
identified by Idris et al. (2012), who found that sucking insect pests may be attract by different colored cards in the field. Most jassids were attracted to the green colored cards, followed by the red, black, and yellow colored cards. The green colored traps also attracted thrip and whiteflies in the okra field (Wagan et al. 2017). Sucking Insect pest effective of plant vegetative growth insect suck leaves and effective plant height increase jassid population decrease plant growth. Insect pest infestations not only reduce the growth but also transmit pathogenic diseases (Sheedi, 1980; Dhaliwal et al., 1981). Jassid is serious pest for okra crop among different sucking insect pests, jassid and whitefly are more serious (Atwal, 1994). Similar results of insect attractions towards the different color were de fined by the green colored card is the most attractant for jassid.

The use of colored sticky trap result showed good managing for okra crop insect pests the green is the most attractive color to the jassid followed by red, black, yellow for jassid. Monitoring and management the color green was also observed to a strong attractant followed red, black, yellow.

\section{References}

1. Alegbejo M., Ogunlana M. and Banwo O. 2008. Survey for incidence of okra mosaic virus in northern Nigeria and evidence for its transmission by beetles. Spanish Journal of Agricultural Research, 6:408-411.

2. Asawalam E.F., Emeasor K.C. and Adieze O. 2007. Influence of some soil amendments on insect pest infestation and damage to okra (Abelmoschus esculentus (L.) Moench in Umudike, Abia State. Res. Journal. Biology Science, 2(1):108-111.

3. Atwal S.N. 1994. Agricultural pests of India \& South-East Asia. Kalyani Publishers, New Delhi, India, pp. 529.

4. Aziz M.A., Hassan M., Ali A., Sohail A. and Sahi S.T. 2011. Impact of abiotic factors on incidence of fruit and shoot infestation of spotted Bollworms Earias spp. on Okra (Abelmoschus esculentus L.). Pakistan Journal. Zoology,43:863-868.

5. Dhaliwal J.S., Sidhu M.S. and Singh G. 1981. Effect of different dates of sowing on sorghum and the incidence of red leaf spot disease and major insect pests in Punjab. Journal of Research, Agriculture University Ludhiana, 1:400-405

6. Idris A.B., Khalid S.A.N. and Mohamad R.M.N. 2012. Effectiveness of Sticky Trap Designs and Colours in Trapping Alate Whitefly, Bemisia tabaci (Gennadius) (Hemiptera: Aleyrodidae) Pertanika. Journal of Tropical Agriculture Science, 35:127-134

7. Lessio F. and Alma A. 2004. Dispersal patterns and chromatic response of Scaphoideus titanus Ball (Homoptera: Cicadellidae) vector of the phytoplasma agent of grapevine Flavescence dorée. Agriculture Forest Entomologist, 6:121-127.

8. Mangrio M.H., 2004. Impact of weding on population of whitefly ,Bemisia tabaci Gen. on okra crop . M.Sc. thesis, Sindh Agriculture TandoJam, Pp 72

9. Olaniyi J.O., Akanbi W.B., Olaniran O.A. and Ilupeju O.T. 2010. The effect of organo - mineral and inorganic fertilizers on the growth, fruit yield, quality and chemical composition of okra. Journal Anim Plant Science 9(1):1135

10. Owen T. 2004. Geoponika: Agricultural pursuits. In; Moore, Science. Journal. \& A Langlet. (2004) An overview of Plants as Insect Repellents. In: Wilcox, M. and Bodeker, G. (eds.) Traditional medicine, Medicinal Plants, and Malaria. Taylor and Francis, London

11. Raja K.M. and Arivudainambi S. 2004. Efficacy of sticky traps against bhendi leaf hopper, Amrasca biguttula biguttula Ishida. Insect Environment, 10:32-32.

12. Shabozoi N.U.K., Abro G.H., Syed T.S. and Awan M.S. 2011. Economic appraisal of pest management options in Okra. Pakistan Journal Zoology, 43:869-878

13. Sheedi M.A. 1980. Arthropods associated with okra (Hibiscus esculentus L) crop. M.Sc. thesis, Sindh Agriculture University, Tandojam. pp. 58.

14. Wagan T.A., Dhaunroo A.A., Jiskani W.M., Sahito M.H., Soomro A.A., Lakho A.B.J., Wagan S.A., Memon Qurat U1 Ain and Tunio S.K. 2017. Evaluation of Four Color Sticky Traps for Monitoring Whitefly and Thrips on Okra Crops at Tando Jam, Pakistan. Journal of Biology, Agriculture \& Healthcare, 7(9):12-15 